van de bundel, toont Werken aan de stad bovenal een goed geordend professioneel academisch bedrijf in werking - alle auteurs presenteren hun onderwerp keurig, met veel oog voor de bestaande literatuur en het beschikbare bronnenmateriaal, een zekere neiging tot volledigheid, en een voorkeur voor onderscheidend wetenschappelijke jargon ('pauper agency ten aanzien van zorgmodaliteiten', 'sociale finaliteit', en 'approximatieve afbakening', om slechts enkele stijlbloempjes te noemen). Sommigen eindigen hun bijdrage weliswaar met een wilde suggestie of een uitdagende hypothese, maar dan altijd met het voorbehoud dat nog veel onderzoek vereist is voordat echte uitspraken in deze kunnen worden gedaan. Slechts een enkele bijdrage valt op door intens schrijfplezier.

Door dit alles mist de bundel als geheel urgentie, en is zij slechts interessant voor collega-historici, voor 'insiders'. Werken aan de stad is, laat daar geen twijfel over bestaan, een passend en liefdevol eerbetoon aan twee belangrijke historici, maar dan wel zonder het vuur en het politieke engagement dat de in de jaren I960 gevormde Catharina Lis en Hugo Soly zelf tekenen. In zijn persoonlijke herinneringen aan het echtpaar laat Alfons K.L. Thijs niet na te wijzen op de betekenis van dat engagement en het trouw blijven aan de idealen van vroeger: 'Zij zijn steeds blijven geloven in de maatschappelijke waarde van de accumulatie van historische kennis ter ondersteuning van de "dialoog tussen verleden en heden"'(p. 26). Hun werk zinderde, ondanks het soms dodelijk saaie cijfermateriaal, onderhuids altijd van een diepe verontwaardiging over maatschappelijke misstanden in verleden en heden. Dat engagement, die klank en die furie, dat is wat je als lezer node mist in Werken aan de stad.

\title{
Paul Knevel
}

Universiteit van Amsterdam

Judith M. Spicksley (ed.), The business and household accounts of Joyce Jeffreys, spinster of Hereford, 1638-1648 (Oxford: Oxford University Press, 2012) xxxi + 4I3 p. ISBN 978-0-I9-726432-4.

Judith Spicksley's edited publication of Joyce Jeffreys' decade-spanning business and household accounting is already the 4Ist instalment of the British Academy's 'Records of social and economic history: new series' - an ongoing effort to publicise social-economic source material on British history, and as such both a remnant from traditional eras where source-publications were highly esteemed cogwheels in historiography's engine of progression, as well as an example for continental/international projects of similar attire. ${ }^{\mathrm{I}}$

The volume starts with a thorough chapter on the editorial method, filled with commentary on the presented text as a linguistic object. Spicksley admits how the forwarded method of editing, in its effort to both preserve the look and feel of the original document as well as make it accessible to a wide range of readers, will 'not delight every reader' (p. xv), although I feel this to be an overstatement - barring particular linguistic study, the editing of the text does not feel intrusive. On the contrary,

I. http://www.britac.ac.uk/pubs/cat/rseh.cfm, August 20I2; Smith, R.M., 'Records of social and economic history', British Academy Review I9 (2012) 29-32. 
the adopted methods of capitalisation, completion and meta-signage - in addition to being well-argued - serve to clarify both text and intent of the original author. Thirdparty research and review is further facilitated through a very worthwhile glossary, several handy indexes, and appendices on the local context, personalia and genealogies. There is, however, one fundamental criticism on usability: at this time (August 20I2) there appears to be no digital version of the edited text, which constitutes an unnecessary and archaic barrier for analysis by other scholars.

Such further study is to be expected, and tangibly supported throughout the chief communicative section of the work. Before providing a complete edited reproduction of Joyce Jeffreys' receipts (p. 8I-I42) and disbursements (p. I43-289, with p. 290-292 being a few added pages on 'debts'), Spicksley offers an introduction spanning 80 pages, covering biographical data on Joyce Jeffreys, the local context, and broad topics like consumption; family, household, religion and charity; medical knowledge and practice; and hobbies and pastimes. It goes without saying that this section interests social, economic and cultural historians alike, a fact of which Spicksley - in her enthusiastic appraisal of the high particular value of the accounts - is duly aware. For starters, Joyce Jeffreys was a spinster, making her accounts a reflection of the socialeconomic activity of a single, elderly female - just the type of subject that has gotten significant interest in recent years. ${ }^{2}$ As Spicksley correctly puts it, 'single women have now become a major focus of historical investigation, as research seeks to reveal not only why women may have resisted the idea of marriage, but also how their single lives would have taken shape within the confines of a society in which adult female status and identity were so intimately tied to marriage' (p. I-2). Even if this statement feels a bit superfluous, as single women have already been 'redeemed' by the likes of Sarti and others, the positive assertion is spot-on when combined with another strong point: the accounts offer a comprehensive view of Joyce Jeffreys' money-lending activities, her 'economic ties' to the community. With an understanding of the importance of credit in early modern society, the reader thus welcomes Spicksley's subchapter on money-lending - even if this section is perhaps too entangled in the particularities of Joyce's local context, while sadly also mostly skipping the 'moral' concepts of reciprocity and trust. 3 The reader's appetite is wetted with crediting to economic agents that also provided a service to the protagonist (thus at least implying reciprocal economic

2. Just a few months ago, several sessions on 'Singles in the city in Northwest Europe' were organised during the European Social Science History Conference in Glasgow (see http:// www2.iisg.nl/esshc/programme.asp? selyear=I2\&find=singles) - one of which attended by Spicksley herself. Concurrently, (female) singles have been headlining subjects in historiographical articles in the Netherlands and elsewhere, for instance S. De Langhe, M. Mechant and I. Devos, 'Regionale verschillen in het leven van ongehuwde moeders op het platteland in de Zuidelijke Nederlanden, I730-I846', Tijdschrift voor Sociale en Economische Geschiedenis 8:I (2OII) 2-28 and J. De Groot, 'Zorgen voor later? De betekenis van de dienstperiode voor jonge vrouwen in het laatmiddeleeuwse Gent herbekeken', Stadsgeschiedenis 6:I (20II) I-I5.

3. This would fit in a larger 'social anthropology of economic behaviour', advocated by Muldrew and Thompson. For more on credit relations and moral concepts, see: C. Muldrew, 'Interpreting the market: the ethics of credit and community relations in early modern England', Social History I8:2 (I993) I63-184; C. Muldrew, The economy of obligation. The culture of credit and social relations in early modern England, New York: Palgrave 200I; E.P. 
cycles), and gift-giving to members of both 'family' and 'kin' (in Tadmor's sense ${ }^{4}$ ) alas, skin-deep description of said elements and the use of dated references leave an aftertaste of superficiality. Sometimes there are what one could consider to be omissions: Joyce Jeffreys was a consumer and producer in her rural locality, while also a consumer of London-borne goods and services, making her of interest to that recent wave of researchers studying the (consumptive) relation between town and country yet there is no reference to Stobart and others. ${ }^{5}$

These remarks should be seen not as criticism per se, but rather as additions to an already tantalising introductory chapter; a continuation of Spicksley's own enthusiasm, if you will. While hardliners may feel there is little excuse for referring to dated works, we mustn't forget that this is a source-edition, not a monograph. As such, while the holistic introduction engenders some superficiality, it also duly provides a good overview of possible avenues of interest regarding the published source. Exactly that, in my opinion, is what we should expect. Now if only there existed a digitalised version of the edition, so an excited scholar could start scrutinising Joyce Jeffreys' accounting right away without first having to type over 200 odd pages...

\section{Tom De Roo}

Universiteit Antwerpen

Centrum voor Stadsgeschiedenis

Daniël Broersma, Het Groene Front voorbij. De agrarische belangenbehartiging door LTO Nederland, 1995-2005. (Groningen/Wageningen: Nederlands Agronomisch Historisch Instituut, 2010) I84 p. IS BN 978903674644I [Historia Agriculturae, 43].

In deze studie brengt Daniël Broersma de recente en korte geschiedenis van koepelorganisatie LTo Nederland, die in I995 ontstond uit de fusie van drie landbouworganisaties, namelijk de Katholieke Nederlandse Boeren- en Tuindersbond (кмвтв), de Nederlandse Christelijke Boeren- en Tuindersbond (свтв) en het Koninklijk Nederlands Landbouw-Comité (KNLC). In 2005, na tien jaren van moeizaam samenwerken, zou LTo als landelijke georganiseerde agrarische belangenvereniging een ingrijpende herstructurering ondergaan. Broersma gaat op zoek naar de oorzaken van de falende

Thompson, 'The moral economy of the English crowd in the eighteenth century', Past and Present 50 (1971) 76-136.

4. Naomi Tadmor, Family and friends in eighteenth-century England: Household, kinship, and patronage, Cambridge: Cambridge University Press, 200I.

5. For reference, once again, sessions at the European Social Science History Conference in Glasgow: 'Town and country: supplying elite consumers in the I8th and Igth centuries' (http://www2.iisg.nl/esshc/programme.asp?selyear=I2\&find=town+and+country). While the time-frame of the sessions was different than Joyce Jeffreys' accounts, Stobart has expressed interest in the earlier historical 'country house' on multiple occasions. His current project, titled 'Consumption in the country house, c. I730-I800' (http://www. northampton.ac.uk/download/3544/consumption-and-the-country-house-I730-1800) is reflected in a community website on the broader subject: http://consumptionandthecountryhouse.ning.com/. 